\title{
Oyunlaştırma Yönteminin Öğrencilerin Motivasyonları Üzerine Etkisi
}

\author{
Zeynep ÖZKAN ${ }^{1}$, Yavuz SAMUR ${ }^{2}$
}

Geliş Tarihi: 2017-05-18

Kabul Tarihi: 2017-11-17

$\ddot{\mathbf{O} z}$

$\mathrm{Bu}$ araştırma çalışmasında oyunlaştırma yönteminin öğrenme sürecinde öğrencilerin motivasyonları üzerindeki etkisini belirlemek amacıyla yayınlanan makalelerin analiz ve değerlendirilmesinin yapıldığı bir içerik analizi yapılmıştır. Çalışma kapsamında arama motorunda "gamification", "motivation" ve "experimental" anahtar kelimeleri kullanılarak 9 tane makaleye ulaşılmış ve mevcut durum açıklanmaya çalışılmıştır. Alanyazın incelendiğinde, oyunlaştırma ve oyun temelli öğrenme arasındaki farkla ilgili yanlış anlaşılmalar olduğu ortaya çıkmıştır. Araştırma kapsamında oyunlaştırma yönteminin motivasyon üzerindeki etkisine yönelik anlamlı fark 7 çalışmada elde edilirken 2 çalışmada anlamlı farklılık bulunmamıştır. ncelenen çalışmalarda en çok kullanılan oyun elementlerini puan, seviye, ödül ve rozet olarak belirlenmiştir. ncelenen çalışmalar ve literatür doğrultusunda oyunlaştırma ile sürecin sonunda öğrencilerin motivasyonları üzerinde olumlu sonuçlar elde edebilmek için öncelikle iyi planlanmış bir öğretim tasarımına ihtiyaç olduğu ortaya çıkmaktadır. Etkili öğretim tasarımları yapılmadığında hiçbir oyun elementi bu eksikliği gideremeyeceği gibi süreçte istenilen hedeflerin de gerçekleşememesine sebep olabilir. Öğrenenlerin kendi gelişimlerini izleyebilecekleri ve bu gelişimlerini devam ettirebilecekleri süreçler özerklik, yetkinlik ve bağlılık duygularını destekleyecek şekilde planlamalar yapılması gerekmektedir. Bu sayede öğrencilerin motivasyonları ve dolayısıyla öğrenmeleri üzerinde olumlu sonuçlar alınabilir.

Anahtar Kelimeler: Oyunlaştırma, motivasyon, oyun, oyun elementleri

\footnotetext{
${ }^{1}$ Bahçeşehir Üniversitesi, Eğitim Bilimleri Enstitüsü, zeynep.ozkan@bahcesehir.edu.tr

2 Yrd. Doç. Dr., Bahçeşehir Üniversitesi, Eğitim Bilimleri Fakültesi, Bilgisayar ve Öğretim Teknolojileri Eğitimi Bölümü, yavuz.samur@es.bau.edu.tr
} 
The Effect of Using Gamification on Students' Motivation

\begin{abstract}
In this research study, a content analysis was carried out to analyse and evaluate the existing articles in order to determine the effect of gamification on students' motivation during the learning process. Within the scope of the study, 9 articles were reached by using the keywords "gamification", "motivation" and "experimental" in an academic search engine and the current literature was explained through the existing articles. When the literature was examined, it was found that there is a misunderstanding related with the difference between gamification and game based learning. Results of the studies showed that there were significant differences on motivation in seven studies while no significant difference was found in two studies. Findings also showed that the most used game elements are points, levels, rewards and badges. It is revealed that a rigorously-planned instructional design is required to obtain positive results on students' motivation at the end of the instruction. When effective instruction is not designed, no game element will be able to eliminate this shortcoming and the desired goals may not be reached during the process. The processes in which learners can observe their progress and continue to develop themselves should be designed in order to support their autonomy, competence and relatedness. Hence, positive results can be obtained on students' motivation and therefore their learning.
\end{abstract}

Keywords: Gamification, motivation, game, game elements 


\section{Giriş}

\section{Oyun, Oyun Temelli Öğrenme, Oyunlaştırma ve Eğitimde Oyunlaştırma}

Oyun; kural temelli, ölçülebilir bir sonucu olan ve bu sonucu etkilemek için oyuna dahil olan oyuncuların çabaladıkları sistemdir (Juul, 2003). Prensky (2007) 'e göre oyun kural, hedef, geri bildirim, sonuç, rekabet, meydan okuma, etkileşim vb. unsurları içeren bir sistemdir. Benzer bir yaklaşımla Järvinen (2008) ise oyunu belli bir ortamı, kuralı, bağlamı olan oyuncunun dahil olduğu sistem olarak tanımlamaktadır.Bu sistemi tasarlamak için oyun tasarımcısının ihtiyaç duyduğu oyun elementleri; hedef, geri bildirim, sonuç, rozet, puan, liderlik tablosu, seviye, meydan okuma, mücadele, rekabet, hikâye, kural, aşılması gereken engel(ler), eğlence, karakter vb. olarak siralanabilir (Arkün-Kocadere ve Samur, 2016; Prensky, 2007; Samur, 2016; Werbach ve Hunter, 2012).

Oyunlar, Hollywood film endüstrisiyle yarışan oldukça büyük bir endüstrisi haline gelmesi ve popülerliğinin ile birlikte karmaşık becerilerin öğrenimi aşamasında gerekli olan etkenlerden olan motivasyonu sağlaması nedeniyle etkili öğrenme süreçleri planlama noktasında eğitimcilerin dikkatini çekmiştir. Öğrenenlerin özelliklerinin farklılaşmasıyla değişen öğrenen profillerine bilginin nasıl öğreneceğine odaklanılması ve dijital oyunlarının gerçeğe çok yakın deneyimler ve öğrenme için yeni fırsatlar sunuyor oluşları oyun temelli öğrenmenin çıkış noktasıdır ve bu yaklaşım ile hem öğrenci merkezli öğrenme süreçleri kurgulanmasına hem de öğrenme deneyimlerinin niteliğinin ve niceliğinin artmasına da imkan sağlar (Meire, 2000; Prensky, 2007; Türker, 2016). Öte yandan oyunların eğitimde kullanılmasıyla eğlence ve eğitimin birlikteliği hem sağlıklı hem de lezzetli olmayan çikolata kaplı brokoliye benzer sonuçlar elde edilmiş olacağına yönelik görüşler de mevcuttur (Bruckman, 1999).

Terim olarak 2000'li yıllar ile birlikte kullanılmaya başlanan ancak temeli 80'li yıllara dayanan oyunlaştırma, bireyin tutum ve davranışını değişikliği gerçekleştirme amacıyla rehabilitasyondan eğitime kadar birbirinden farklı birçok alanda tercih edilen bir yaklaşımdır (Arkün-Kocadere ve Samur, 2016; Juárez ve Carballo, 2016; Kim, Park ve Baek).

Oyunlaştırma, oyun elementlerinin oyun olmayan içeriklerin tasarımında kullanılmasıdır (Deterding, Dixon, Khaled ve Nackle, 2011; Deterding, O’Hara, Sicart, Dixon ve Nacke, 2011; Deterding, Sicart, Nacke, O’Hara, ve Dixon, 2011; Werbach, 2014; Werbach ve Hunter, 2012). Bir diğer deyişle oyunlaştırma, oyun elementlerinin oyun olmayan içeriklerde kullanıcıların deneyimini ve ilgisini arttırmak amacıyla kullanılmasıdır 
(Domínguez ve diğ., 2013). Son dönemdeki en popüler oyunlaştırma örneklerinden birisi olan Nike+ uygulaması dünya çapında 18 milyar civarında kullanıcı olan bir uygulamadır ve kullanıcıların spor alışkanlığg edinmesinde ve bu alışkanlığın sürekliliğine yönelik memnun edici sonuçlar vermiştir. Yine Stockholm'de metroda uygulanan piyano merdiven uygulaması bireyleri daha fazla merdiven kullanma davranışına yönlendirebilmiştir (Piano Staircase, 2009).

Her bir öğrenciye avatar verilerek öğretmenlerin sanal bir sınıf oluşturularak öğrencinin gelişiminin hem öğretmen hem de öğrenci velisi tarafından izlenebilmesini sağlan ClassDojo sınıf yönetimi için tercih edilen oyunlaştırma uygulaması eğitimde oyunlaştırma örneği olarak verilebilir. Bir diğer örnek ise kullanıcıların yabancı dil öğretimi için kullandığı Duolingo'dur. Sınıftaki öğrencilerin aktif olarak katılabilecekleri sınavlar hazırlamayı ve öğrencilerin her birinin performansını öğretmen tarafından takip etmeyi kolaylaştıran Kahoot eğitimde kullan diğer oyunlaştırma örneklerindendir.

Eğitimde oyunlaştırma yönteminin tercih edildiği durumlarda tasarım aşamasında ilk olarak akla ödül, puan, rozet gibi oyun elementleri gelmektedir. Bundan dolayı oyunlaştırmanın öğreneni sadece ödüllendirdiği bir sistem olduğu ve bu şekilde kurgulanan bir sürecin öğrencilerin motivasyonunu üzerinde olumsuz etkileri olduğu yönünde görüşler bulunmaktadır (Buckley ve Doyle, 2016).

Öğrencilere ödül (Denny, 2013), rozet (Hakulinen, Auvinen ve Korhonen, 2015) ve puan (Hanus ve Fox, 2015) verilmesi ve liderlik tablosunun kullanılmasının (Domìnguez, ve diğ., 2013; de-Marcos, Domínguez, Saenz-de-Navarrete ve Pagés, 2014; Hanus ve Fox, 2015) öğrencinin motivasyonuna olumsuz yönde etkilediği ve öğrenmede anlamlı fark yaratmadığını gösteren çalışmalar alanyazın incelendiğinde görülmektedir. Ayrıca oyunlaştırma öğrenme sürecinde rekabet oluşmasına neden olabileceğinden dolayı birçok eğitim kuramıyla çelişkiler içermesi de eğitimde oyunlaştırma kullanımına yönelik yapılan eleştirilerden bir diğeridir (Yıldırım ve Demir, 2014).

Öte yandan eğitimde halihazırda oyunlaştırma benzeri süreçler bulunmaktadır; öğrenciler istenen öğrenme hedefini gerçekleştirdiklerinde puanlar kazanırlar, kazandıkları puanlar notlara dönüşür ve akademik sene sonunda bir sonraki seviyeye yani bir üst sınıfa geçerler (Buckley ve Doyle, 2016; Lee ve Hammer, 2011). Oyunlaştırma ile öğrencilerin öğrenme sürecinde eğlenmelerine (Cheong, Cheong ve Fillippou, 2013), aşamalı zorluklarla karşılaşılması, beklenmedik ipuçlarının öğrenciye verilmesinin (Dong, Dontcheva, Karraholios, Newman ve Ackerman, 2012) ya da kullanıcıya zaman yönetiminde avantaj 
sağlamasıyla (Fitz-Walter, Tjonderonegoro, ve Wyeth, 2011) motivasyonu pozitif yönde etkiler. Benzer bir yaklaşımla Samur (2015) oyunlaştırma yeni ve popüler bir yöntem olmasına karşın eğitim alanında da yapılan kısıtlı sayıda çalışma incelendiğinde genellikle bu yöntemin dahil edildiği süreçlerde olumlu sonuçlar elde edildiğini belirtir. Yine benzer bir yaklaşımla Buckley ve Doyle (2016), oyunlaştırma bireylere deneme, hata yapma, deneyim kazanma fırsatı sunarak başarısızlığın bir son olmadığının anlaşılarak bireyin hedefine ulaşabilmesini sağladığını yönünde bir değerlendirmede bulunmaktadır. Ayrıca puan, rozet ve liderlik tablosu gibi oyun elementleri doğrudan sonuca yönelik olarak kullanılmadan ve bireyin gelişimini izleyerek yeterli geri bildirim verilebilmesine yardımcı olabilir (Buckley ve Doyle, 2016; Hakulinen ve diğ., 2015; Werbach ve Hunter, 2012).

Oyun tasarımı ile benzer noktaları oyunlaştırma tasarımında oyun elementlerinden hangilerinin ve nasıl kullanılacağı oyunlaştırma ile hedeflenenin ne olduğuna ve kullanması hedeflenen kitleye bağlı olarak değişiklik göstermektedir. Bu noktada oyun tasarım sürecinin temelini oluşturan akış teorisini (flow theory) ve oyunlaştırma ile bireyin motivasyonuna olumlu yönde katkıda bulunabilmek adına öz-belirleme teorisini (self-determination theory) göz önüne alarak oyunlaştırma etkili tasarımını gerçekleştirme sürecine katkı sağlayabilir.

\section{Akıș Teorisi}

Satranç oyuncuları, dağcılar, ressamlar ve dansçılar nasıl süreçte temel ihtiyaçlarını gidermeyi bile unutup ilgilerini kaybetmeden içinde bulundukları eylemi nasıl tamamladığına yönelik olarak ortaya çıkan akış teorisi Csikzentmihalyi tarafından ortaya konmuştur (Nakamura ve Csikzentmihalyi, 2002). nsanlar yapabileceklerinden daha kolay bir şeyleri yaparken sıkılıp bırakırlar, benzer olarak yapabileceklerinin üstünde zorluğa sahip bir şeyleri yaparken ise hayal kırıklığına uğrayıp yine yarıda bırakırlar (Prensky, 2007). Bu nedenle de iyi kurgulanmış deneyimlerin sahip olması gereken en önemli özellik kişinin yeteneklerine ve potansiyeline uygun zorlukta olmasıdır ve bu deneyimin sahip olması gereken diğer özellikleri ise bireye açık ve net hedefler sunup süreçte geri bildirimler ile bireyin desteklenmesidir (Nakamura ve Csikzentmihalyi, 2002). Csikzentmihalyi'e (2014) göre bireylerin bir eylemi yapmaya devam ettiren unsurun motivasyon olduğunu ve motivasyonun ise akış ve eğlence ile sağlanmaktadır.

\section{Motivasyon ve Öz Belirleme Kuramı}

Motivasyon hareket geçirme anlamına gelen Latince motivous kelimesinden gelmektedir (Werbach ve Hunter, 2012). Motivasyon durum ve zaman içinde birey ile eylem arasındaki 
etkileşimdir (Werbach ve Hunter, 2012). Motivasyon, bir şeyi yapmak için harekete geçmedir (Ryan ve Deci, 2000a). çsel motivasyon bireyin bir eylemi ilgi duyduğu ve hoşlandığı için yapması ve dışsal motivasyon ise elde edilecek sonuca bağlı olarak yapması seklinde tanımlanabilir (Ryan ve Deci, 2000b). çsel motivasyon, kişinin kendini tatmin edebilme amacıyla ilgi ve merakı doğrultusunda kendi isteği ile harekete geçmesine neden olur (Gagné ve Deci, 2005; Werbach ve Hunter, 2012) Dişsal motivasyon, içsel motivasyondan farklı olarak kişinin bir faaliyete katılmak için somut veya sözlü ödüller gibi sürecin direkt olarak sonucu ile bağ kurmasına neden olur ve burada birey için önemli olan etkinlik değil sonuçtur (Gagné ve Deci, 2005).

Her insanın motivasyon kaynakları ve durumlara karşı sahip oldukları motivasyon durumları birbirlerinden farklıdır (Ryan ve Deci, 2000a). Motivasyon eksikliği ve motivasyon ayrımını açıklamaya yönelik olarak öz-belirleme kuramı (self-determination theory) kullanılmaktadır. (Ryan ve Deci, 2000a; Ryan ve Deci, 2000b; Gagné ve Deci, 2005). Özbelirleme kuramı, bireylerin motivasyonlarını ödül, bitiş tarihi vb. kontrol mekanizmaları olumsuz etkilediği ve bu nedenle de motivasyonu yetki (competence), bağlilık (relatedness) ve özerklik (autonmy) unsurları ile ilişkilendirerek açıklamaktadır (Deci ve Ryan, 2008; Deci, Koestner ve Ryan, 2001; Ryan ve Deci, 2000a, Ryan ve Deci, 2000b; Werbach ve Hunter, 2012). Ayrıca öz-belirleme kuramı, içsel motivasyon ve dışsal motivasyon haricinde bireylerin motivasyonsuzluk durumunu da ortaya koymuştur. Motivasyonsuzluk durumunda bireyin davranışlarında amaç ve nedensellik bulunmamaktadır (Ryan ve Deci, 2000b).

Öz belirleme kuramının bir alt başlığı olarak bilişsel değerlendirme kuramı (cognitive evaluation theory, CET) Deci ve Ryan tarafından ortaya konmuştur. Bilişsel değerlendirme kuramı, bireyin içinde yaşamakta olduğu toplum ve kültürel bağlamın içsel motivasyonu nasıl etkilediğini açıklamaya yöneliktir (Ryan ve Deci, 2000a; Ryan ve Deci, 2000b; Deci ve diğ., 2001). Bilişsel değerlendirme kuramı, içsel motivasyonun öz belirleme kuramı ve bireyin psikolojik ihtiyaçları üzerine temellendirildiğini söyler (Deci ve diğ., 2001). Bu kurama göre eylem sırasında bireyin yetkinlik duygusuna yön veren kişiler arası bağlamlar ve unsurlar (geri bildirim, ödül vb.) içsel motivasyonu tetikleyebilir (Ryan ve Deci, 2000a; Ryan ve Deci, 2000b; Deci ve diğ., 2001). Bu süreçte kullanılabilecek olan ödüller; sözlü ödüller (verbal reward) ve somut ödüller (tangible reward) olarak ikiye ayrılmaktadır ve ödüllerin bilgilendirme ve kontrol olmak üzere iki yönü vardır (Deci ve diğ., 2001). Bilişsel değerlendirme kuramına göre ödüller eğer performansa yönelik olarak verilip, bireyin üzerinde kontrol mekanizması olarak kullanılırsa motivasyon zayıflarken bunu tam tersi 
olarak bireyin psikolojik ihtiyaçlarını karşılamak amacıyla optimal bir zorluktaki süreç içerisinde bireyin özerklik ve yetkinlik duygularına zarar vermeyecek şekilde kullanılırsa içsel motivasyonu tetikleyebilir (Ryan ve Deci, 2000a; Ryan ve Deci, 2000b; Deci ve diğ., 2001). Özetlemek gerekirse bireylerin yetkinlik ve özerklik unsurları desteklenerek süreç kurgulanırsa bireyin içsel motivasyonu zarar görmeyecektir. (Ryan ve Deci, 2000a).

Öz belirleme kuramının bir diğer alt başlığı ise örgütsel bütünleştirme kuramıdır (Organismic Integration Theory (OIT). Bu kuram diş motivasyonu ve diş motivasyonun birey tarafından nasıl içselleştirdiğini açıklamaya yöneliktir (Ryan ve Deci, 2000a; Nickholson, 2012). OIT motivasyon taksonomisi ile motivasyonu açıklanmaya çalışır ve dış motivasyonu ise dört biçimde ele alır;

1. Dişarıdan Düzenleme (External Regulation), en az özerklik veren ve ödül vb. sonuca odaklı olandır (Ryan ve Deci, 2000a). Davranışları belirleyen sebep ödül almak ya da cezadan kaçınmaktır. Örneğin, teneffüse çıkabilmesi için ödev yapması gerektiğini bilen öğrencinin ödev yapma motivasyonu bu türden sayılabilir.

2. çe Yansıtma (Introjection Regulation), bireyin kendisinin ya da başkalarının onayına odaklı olan dişsal motivasyondur (Ryan ve Deci, 2000a). Örneğin, öğrencinin öğretmenin gözünde iyi bir izlenim (çalışkanlık vb.) bırakmak amacıyla ödev yapma motivasyonu bu türden bir motivasyon sayılabilir.

3. Tanımlama (Identification), bireye bir miktar özerklik veren ve bilinçli hedeflere yönelik olan dişsal motivasyondur (Ryan ve Deci, 2000a). Örneğin, öğrencinin ödevin öğrenme aşamasında kendisine fayda sağlayacağını düşünmesinden dolayı bir ödev yapma motivasyonuna sahip olması bu türden bir dışsal motivasyon olarak kabul edilebilir.

4. Bütünleştirme (Integration), dışsal motivasyon formları arasında en özerk ve bireyin kendi ihtiyaçlarına yönelik hedef ve nedenler sunan motivasyon türüdür (Ryan ve Deci, 2000a). Örneğin, öğrencinin ödevi kendine ait bir sorumluluk olduğunu kabul ederek geliştirdiği ödev yapma motivasyonu bu türden bir motivasyon sayılabilir.

Örgütsel bütünleştirme kuramı (OIT) motivasyon türleri taksonomisi kişinin davranışından kaynaklanan motivasyonun kişinin kendisinden ne derece etkilendiğine bağlı olarak düzenlenmiştir ve bireyin dış etkenleri kişisel ihtiyaç ve amaçları ile bütünleştirmesinin dış etkenin tek başına kullanılmasından daha etkili olabileceğini söyler (Nickholson, 2012; Ryan ve Deci, 2000a; Ryan ve Deci, 2000b). 
Araştırma Soruları

1. Araştırma kapsamında incelen çalışmaların yayınlandığı yıllara bakıldığında artış göstermekte midir?

2. Araştırma kapsamında incelen çalışmaların yer aldığı dergiler daha çok hangi alanlardadır ve etki faktörleri nedir?

3. Araştırma kapsamında incelenen çalışmalarda en çok hangi bağımlı değişkene yönelik olarak veri toplama araçları kullanılmıştır?

4. Araştırma kapsamında incelenen çalışmalarda en çok hangi oyun elementleri kullanılmıştır?

5. Araştırma kapsamında incelenen çalışmaların örneklem büyüklükleri genellenebilir seviyede midir?

6. Araştırma kapsamında incelenen çalışmalarda en çok hangi örneklem düzeyi çalışılmıştır?

7. Araştırma kapsamında incelenen çalışmaların bağımsız değişkenleri nelerdir?

8. Araştırma kapsamında incelenen deneysel çalışmalarda araştırma deseni olarak en çok hangisi tercih edilmiştir?

9. Araştırma kapsamında incelenen çalışmaların sonuçları nedir?

Daha önce de belirtildiği üzere oyunlaştırmanın yeni ve popüler bir yöntem oluşunun yanı sıra oyun temelli öğrenmeye göre daha az maliyetli olması sebebiyle son dönemde sıkça öğrenme sürecinde tercih edilmektedir. Bu çalışmada eğitimde oyunlaştırma örneklerinin yer aldığı deneysel çalışmalarda , öğrenci motivasyonu üzerinde nasıl etkilerde bulunduğu incelenecek ve çalışmalarda kullanılan veri toplama araçları, örneklem düzeyi, bağımlı değişkenleri, tercih edilen oyun elementleri ve araştırma deseni derinlemesine incelenerek alan yazını özetlenecektir. Çalışmanın örneklemine dahil edilen çalışmalar üzerinden oyun elementlerinin öğrenenlerin akademik başarısı, derse katılım, devamsızlık ve motivasyonu üzerinde nasıl etkilerde bulunduğu incelenecek ve eğitimde oyunlaştırma süreçlerinde daha etkili sonuçlar alınmasına yönelik önerilerde bulunulması bu çalışma ile amaçlanmıştır. Sunulacak öneriler gelecekteki eğitimde oyunlaştırma uygulamalarında daha etkili sonuç elde edilmesine yönelik bir yol haritası sunarak alana katkıda bulanacaktır.

\section{Yöntem}

\section{Araştırma Modeli}

Bu çalışma, öğrenme sürecinin oyunlaştırılmasının öğrencinin akademik başarısı, derse katılımı ve motivasyonu üzerindeki etkisini saptamak ve var olan durumu betimlemek 
amacıyla nitel araştırma yöntemlerinden betimsel içerik analizi ile gerçekleştirilen bir tarama araştırmasıdır.

Tarama araştırmaları, geniş kitlelerin fikirlerini, tutumlarını ve özelliklerini tasvir etmeyi yani karşı karşıya kalınan durumun fotoğrafını sunmayı amaçlayan çalışmalardır (Büyüköztürk, Akgün, Karadeniz, Demirel ve Kılıç, 2016). çerik analizi, kurallara bağlı olarak bir metnin bazı kelime ya da bölümlerinin kategoriler altında özetlendiği yinelenebilir, objektif ve sistematik gerçekleştirilen bir tekniktir (Büyüköztürk ve diğ., 2016).

\section{Evren ve Örneklem}

Öğrenme sürecinde oyun ve oyunlaştırma uygulamalarının öğrenci akademik başarısı ve derse katılımı, bireylerin ilgi ve motivasyonları üzerindeki etkileri belirlemek amacıyla yürütülmüş olan ngilizce makalelerdir. Araştırmanın örneklemini ise birden fazla veri tabanını tarayan federe arama motoru BAU Academic Search veri tabanından yararlanılarak ulaşılmıştır. Araştırma kapsamında kullanılan anahtar kelimeler aracılığı ile filtrelenmiş olan makaleler oluşturmaktadir.

\section{Verilerin Toplanması}

Araştırmada örneklemin belirlenmesi aşamasında veri tabanında yararlanılarak makalelerin belirlenmesinde sistematik bir yöntem izlenmiştir.

1. Bahçeşehir Üniversitesi veri tabanları listesinde BAU Academic Search veri tabanı seçilerek Federe arama motoru ile birden fazla veri tabanından arama yapılmıştır.

2. Kasım 2016'da Çıkan arama sayfasından gelişmiş arama tercih edilerek "gamification" ve "motivation" ve "experimental" anahtar kelimeleri kullanılarak 89 çalışmaya ulaşılmıştır.

3. Çalışmaların kütüphane koleksiyonunda bulunmasına önem verildiğinde 75 çalışmaya ulaşılmıştır.

4. Kaynak tipleri sadece akademik dergiler olarak tercih edildiğinde 26 çalışmaya ulaşılmıştır.

5. Yapılan arama hakemli dergilerle sınırlandığında ulaşılan çalışma sayısı 25 olmuştur.

6. Ulaşılan çalışmalar gamification konusu ile sınırlandırıldı̆̆ında 10 çalışmaya ulaşılmıştır.

7. Tercih edilen anahtar kelimelerin sadece özet kısmında özellikle yer almasına önem verildiğinde 10 çalışmaya ulaşılmıştır.

8. Bu makaleler arasından sadece nicel veri toplama yöntemlerini kullanan makaleler dahil edilmiştir, diğer nitel veri toplayan ve betimsel olan çalışmalar dahil edilmemiştir. 
9. Toplamda araştırma amacına uygun 10 makaleye ulaşılmıştır ancak makalelerden birinin yönteminin tarama (survey) olması nedeniyle biri elenmiştir.

10. Sonuç olarak araştırma örneklemi olarak 9 makale olarak belirlenmiştir.

\section{Bulgular}

\section{Araştırma Kapsamında ncelenen Çalışmaların Yayınlandığı Yıllar}

Tablo 1'de araştırma kapsamında incelenen 9 çalışmanın hangi yıllarda gerçekleştirildiği yer almaktadır. Yapılan çalışmaların \%22'si 2015 yılında, \% 78'i 2016 yılında gerçekleştirilmiştir.

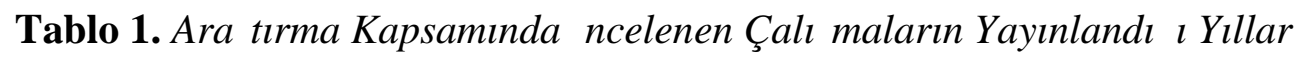

\begin{tabular}{lcc}
\hline Y1llar & Frekans (f) & Yüzde (\%) \\
\hline 2015 & 2 & 22 \\
2016 & 7 & 78 \\
Toplam & 9 & 100 \\
\hline
\end{tabular}

\section{Araştırma Kapsamında ncelenen Çalışmaların Yer Aldığı Dergiler}

Tablo 2'de araştırma kapsamında incelenen yayınların yer aldığı dergilere yönelik bilgi bulunmaktadır. Yapılan çalışmalar Atten Percept Psychophysy, British Journal Of Educational Technology, Computers in Human Behavior, International Journal Human Computer Studies, International Journal of Educational Technology Higher Education, International Journal of Emerging Technologies in Learning, International Journal of Engineering Education, Journal of Interactive Marketing, smart Learning Environment ve The Electronic Journal of e-Learning adlı dergilerde yer almıştır.

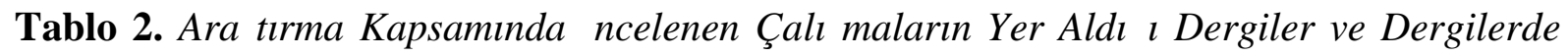
buluma siklıkları

\begin{tabular}{llc}
\hline Dergi Adı & Alan & Etki Faktörü \\
\hline Attention Perception \& Psychophysics & Psikoloji & 1.174 \\
British Journal of Educational Technology & Eğitim Teknolojisi & 1.333 \\
Computers in Human Behavior & Eğitim Teknolojisi & 1.595 \\
International Journal of Educational Technology Higher Education & Eğitim Teknolojisi & 0.425 \\
International Journal of Emerging Technologies in Learning & Eğitim Teknolojisi & 0.218 \\
International Journal of Engineering Education & Mühendislik & 0.386 \\
Journal of Interactive Marketing & Pazarlama & 2.754 \\
Smart Learning Environment & Eğitim Teknolojisi & 1.658 \\
The Electronic Journal of e-Learning & Eğitim Teknolojisi & 0.424 \\
\hline
\end{tabular}

* Etki Faktörleri 2016 yılına aittir 


\section{Araştırma Kapsamında ncelenen Çalışmalarda Kullanılan Veri Toplama Araçları}

Tablo 3'te araştırma kapsamında incelenen yayınlarda kullanılan veri toplama araçları belirtilmiştir. ncelenen çalışmalarda \% 34,6 ile en çok motivasyon anketi veri toplama aracı olarak kullanılırken bunu \% 19.2 ile öğrenme kazançlarına yönelik kullanılan ölçme araçları izlemektedir. Kullanılan veri toplama araçlarından \% 3.85 ile en az kullanılan veri toplama araçları akış testi, biyometrik özelliklere yönelik kullanılan ölçümler olmuştur.

\section{Araştırma Kapsamında ncelenen Çalışmalarda Kullanılan Oyun Elementleri}

Tablo 4'te araştırma kapsamında incelenen çalışmalarda kullanılan oyun elementlerine yönelik bilgi sunulmuştur. Yapılan çalışmalarda \%16,1 ile puan kullanılırken \%3,23 ile ilerleme çubuğu ve zaman en az tercih edilen oyun elementleri olmuştur.

\section{Araştırma Kapsamında ncelenen Çalışmaların Örneklem Büyüklükleri}

Tablo 5'te araştırma kapsamında incelenen çalışmaların örneklem büyüklüklerine yönelik bilgi sunulmuştur. ncelenen çalışmalarda en çok \% 44'lük oranla 20 ile 54 arasında değişen büyüklükteki örneklemler tercih edilmiştir. Ardından \% 22'şerlik oran ile 55-89 ve 90-124 katılımcının yer aldığı örneklemler tercih edilirken en az 160-194 kişinin dahil olduğu çalışmalar gerçekleştirilmiştir.

Tablo 5. Araştırma Kapsamında ncelenen Çalışmaların Örneklem Büyüklükleri

\begin{tabular}{lcc}
\hline Örneklem Büyüklüğ̈̈ & Frekans (f) & Yüzde (\%) \\
\hline $20-54$ & 4 & 44.4 \\
$55-89$ & 2 & 22.2 \\
$90-124$ & 2 & 22.2 \\
$160-194$ & 1 & 11.1 \\
Toplam & 9 & 100 \\
\hline
\end{tabular}

Araştırma Kapsamında ncelenen Çalışmaların Örneklem Düzeyleri

Tablo 6' da araştırma kapsamında incelenen çalışmaların örneklem düzeylerine yönelik bilgi sunulmuştur. ncelenen çalışmalarda \%40 ile en çok lisans düzeyinde çalışma yapılırken bunu \% 30 ile ilköğretim ve diğer seviyeler takip etmektedir.

Tablo 6. Araştırma Kapsamında ncelenen Çalışmaların Örneklem Düzeyleri

\begin{tabular}{lcc}
\hline Örneklem Düzeyi & Frekans (f) & Yüzde (\%) \\
\hline lkokul & 2 & 22.2 \\
Ortaokul & 1 & 11.1 \\
Lisans & 4 & 44.4 \\
Diğer (müşteri, hastane) & 2 & 22.2 \\
Toplam & 9 & 100 \\
\hline
\end{tabular}




\section{Araştırmada ncelenen Çalışmaların Bağımsız Değişkenleri}

Tablo 7'de araştırma kapsamında incelenen makalelerde incelenen bağımsız değişkenlere yönelik bilgiler sunulmuştur. ncelenen çalışmalarda bă̆ımsız değişken \%45,5 ile oyunlaştırılmış süreçler ve oyun kullanılan süreçler olmuştur. \%9 ile en az incelenen bağımsız değişken e-öğrenme ortamlarının etkisi olmuştur.

Tablo 7. Araştırmada ncelenen Çalışmaların Bă̆ımsız Değişkenleri

\begin{tabular}{lccc}
\hline Yazar & $\begin{array}{l}\text { Oyunlaştırılmış } \\
\text { süreç (ders planı, } \\
\text { teşhis gibi) }\end{array}$ & $\begin{array}{l}\text { Dijital Oyun/Mobil } \\
\text { Oyun/Video } \\
\text { Oyunu/Masa Oyunu }\end{array}$ & $\begin{array}{l}\text { Oyunlaştırılmış e- } \\
\text { öğrenme } \\
\text { ortamları }\end{array}$ \\
\hline Hamzah, Ali, Saman,Yusoff ve Yacob, 2015 & & $\mathrm{x}$ & $\mathrm{x}$ \\
Siemens, Smith, Fisher,Thyroff ve Killion, 2015 & & $\mathrm{x}$ & \\
Chen, Liu ve Hwang, 2016 & $\mathrm{x}$ & $\mathrm{x}$ & \\
Cózar-Gutierrez ve Sáez-López, 2016 & $\mathrm{x}$ & & \\
Fotoris,Mastoras, Leinfeliner ve Rosunally, 2016 & $\mathrm{x}$ & & \\
González, Gómez, Navarro, Cairós, Quirce, & $\mathrm{x}$ & $\mathrm{x}$ & \\
Toledo ve Marrero-Gordillo, 2016 & $\mathrm{x}$ & $\mathrm{x}$ & \\
Juárez ve Carballo, 2016 & & 5 & 1 \\
Pesare, Roselli, Corriero ve Rossano, 2016 & 5 & 45.5 & 9 \\
Roper ve Vecera, 2016 & 45.5 & & \\
\hline Frekans (f) & & & \\
Yüzde (\%) & & & \\
\hline
\end{tabular}

\section{Araştırmada ncelenen Çalışmaların Araştırma Desenleri}

Tablo 8'da araştırma kapsamında incelenen çalışmalarda kullanılan araştırma desenlerine yönelik bilgi yer almaktadır. Çalışmalarda ön-test son-test kontrol gruplu deneysel desen, öntest son-test kontrol gruplu yarı deneysel desen, tek gruplu ön-test son-test deneysel desen, tek gruplu ön-test son-test yarı deneysel desen kullanılmıştır.

Tablo 8. Araştırmada ncelenen Çalışmaların Araştırma Desenleri

\begin{tabular}{lcc}
\hline Araştırma Deseni & Frekans (f) & Yüzde (\%) \\
\hline Ön-Test Son Test Kontrol Gruplu Deneysel Desen & 3 & 33.3 \\
Ön-Test Son Test Kontrol Gruplu Yarı Deneysel Desen & 3 & 33.3 \\
Tek Gruplu Ön-Test Son-Test Deneysel Desen & 2 & 22.2 \\
Tek Gruplu Ön-Test Son-Test Yarı Deneysel Desen & 1 & 11.1 \\
Toplam & 9 & 100 \\
\hline
\end{tabular}




\section{Araştırmada Kapsamında ncelenen Çalışmaların Sonuçları}

$\mathrm{Bu}$ başlık altında araştırma kapsamında incelenen yayınların sonuçları yer almaktadır ve Tablo 9'da araştırma kapsamın incelenen yayınların sonuçlarına yönelik bilgi sunulmuştur.

Tablo 9. Araştırmada Kapsamında ncelenen Çalışmaların Sonuçları

\begin{tabular}{|c|c|c|c|c|}
\hline Yazar & $\begin{array}{l}\text { Kullanılan Oyun } \\
\text { Elementleri }\end{array}$ & $\begin{array}{l}\text { Anlaml } \\
1 \text { Fark } \\
\text { Var }\end{array}$ & $\begin{array}{l}\text { Anlaml } \\
1 \text { Fark } \\
\text { Yok }\end{array}$ & Sonuç Özeti \\
\hline $\begin{array}{l}\text { Hamzah, Ali, } \\
\text { Saman,Yusoff ve } \\
\text { Yacob, } 2015\end{array}$ & $\begin{array}{l}\text { Rozet, ödül ( çsel ve } \\
\text { dişsal motivasyona } \\
\text { yönelik), düzey ve } \\
\text { sorumluluk }\end{array}$ & + & & $\begin{array}{l}\text { ARCS+G kullanılan deney grubunun } \\
\text { motivasyonu ile kontrol grubu motivasyonu } \\
\text { arasında anlamlı fark bulunmuştur. }\end{array}$ \\
\hline $\begin{array}{l}\text { Siemens, Smith, } \\
\text { Fisher,Thyroff ve } \\
\text { Killion, } 2015\end{array}$ & $\begin{array}{l}\text { Geri bildirim verme } \\
\text { amacı ile yetki ve } \\
\text { ilerleme çubuğu }\end{array}$ & + & & $\begin{array}{l}\text { Oyun bireysel ise geri bildirimlerin farklı türde } \\
\text { verilmesi anlamlı fark yaratmıştır. Bireye yetki } \\
\text { vermek sosyal bağlam içinde ilerleme çubuğuna } \\
\text { göre daha olumlu sonuçlar veriyor. }\end{array}$ \\
\hline $\begin{array}{l}\text { Chen, Liu ve } \\
\text { Hwang, } 2016\end{array}$ & $\begin{array}{l}\text { Puan, geri bildirim, } \\
\text { düzey }\end{array}$ & + & & $\begin{array}{l}\text { Oyun yaklaşımı, öğrenen öğrencilerin öğrenme } \\
\text { motivasyonu üzerinde oyun yaklaşımı olmadan } \\
\text { öğrenen öğrencilere göre anlamlı fark } \\
\text { göstermiştir. }\end{array}$ \\
\hline $\begin{array}{l}\text { Cózar-Gutierrez ve } \\
\text { Sáez-López, } 2016\end{array}$ & $\begin{array}{l}\text { Geri bildirim, yetki, } \\
\text { özelleştirme }\end{array}$ & + & & $\begin{array}{l}\text { Öğrencilerin ilgisi, motivasyonu ve yeniliğe } \\
\text { yönelik tutumları üzerinde anlamlı farklılık } \\
\text { bulunmuştur. }\end{array}$ \\
\hline $\begin{array}{l}\text { Fotoris,Mastoras, } \\
\text { Leinfeliner ve } \\
\text { Rosunally, } 2016\end{array}$ & $\begin{array}{l}\text { Rozet, liderlik tablosu, } \\
\text { puan, geri bildirim }\end{array}$ & + & & $\begin{array}{l}\text { Öğrenci davranışları üzerinden yapılan çıkarım } \\
\text { sonucunda öğrenme motivasyonun olumlu } \\
\text { etkilendiği sonucuna varılmıştır. }\end{array}$ \\
\hline $\begin{array}{l}\text { González, Gómez, } \\
\text { Navarro, Cairós, } \\
\text { Quirce, Toledo } \\
\text { veMarrero-Gordillo, } \\
2016\end{array}$ & $\begin{array}{l}\text { Rozet, liderlik tablosu, } \\
\text { meydan okuma, puan, } \\
\text { zaman }\end{array}$ & + & & $\begin{array}{l}\text { Öğrencilerin biyometrik özellikleri üzerinde } \\
\text { anlamlı fark görülmemiş olsa da çalışma } \\
\text { sonucunda öğrenmelerinde ve motivasyonları } \\
\text { üzerinde olumlu sonuçlar bulunmuştur. }\end{array}$ \\
\hline $\begin{array}{l}\text { Juárez ve Carballo, } \\
2016\end{array}$ & $\begin{array}{l}\text { Rozet, puan, düzey } \\
\text { (aşamalı zorluk) }\end{array}$ & & $\mathrm{x}$ & $\begin{array}{l}\text { Öğrenmede anlamlı etki bulunamamış ancak } \\
\text { deney grubunun öğrenme kazancı kontrol } \\
\text { grubundan daha yüksektir. Oyunlaştırmanın } \\
\text { dersin bir parçası olması öğrenci motivasyonunu } \\
\text { olumlu etkilemiştir. }\end{array}$ \\
\hline $\begin{array}{l}\text { Pesare, Roselli, } \\
\text { Corriero ve } \\
\text { Rossano, } 2016\end{array}$ & Rozet, ödül, puan, düzey & + & & $\begin{array}{l}\text { Düşük motivasyona sahip bireylerin motivasyon } \\
\text { düzeyleri oyunlaştırma yöntemi ile olumlu } \\
\text { etkilenmiştir. Ancak düşük motivasyonlu } \\
\text { bireylerin ögrenmesi üzerinde katkı } \\
\text { sağlanmamıştır. }\end{array}$ \\
\hline $\begin{array}{l}\text { Roper ve Vecera, } \\
2016\end{array}$ & Ödül & & $\mathrm{x}$ & $\begin{array}{l}\text { Farklı imajlar ile ödül verilmesi bireylerin } \\
\text { motivasyonunda anlamlı bir farklılık } \\
\text { yaratmamıştır. }\end{array}$ \\
\hline Frekans (f) & & 7 & 2 & \\
\hline Yüzde (\%) & & 78 & 22 & \\
\hline
\end{tabular}




\section{Sonuç ve Tartışma}

$\mathrm{Bu}$ bölümde araştırma kapsamında incelenen çalışmalardan elde edilen bulgular doğrultusunda varılan sonuçlar değerlendirilecektir. Araştırma kapsamında oyunlaştırmanın bireyin motivasyonu üzerindeki etkilerini inceleyen çalışmalar ülkemizde sinırlı olup dünyada da oldukça az sayıda çalışmaya ulaşılmış ve çalışmaların 2015 yılından itibaren yapıldı̆̆ ortaya çıkmıştır. Oyunlaştırma yöntemi gün geçtikçe daha çok tercih edilir olmuştur ve bu durumun bir göstergesi de 2016 yılına ait 2015 yılına göre çok daha fazla çalışmaya ulaşılmış olmasidir.

Araştırma kapsamında incelenen çalışmaların yayınlandıkları dergiler daha çok Eğitim Teknolojisi alanında yayın yapmaktadır. Bir dergide yayınlanan çalışmaları ne kadar atıf aldığını gösteren etki faktörü, araştırma kapsamında incelenen çalışmalar, yayınları yüksek sayıda atıf alan dergilerde yayınlandığı belirlenmiştir. Ayrıca araştırma kapsamında ulaşılabilen çalışmalarda anket, görüşme, sınav, gözlem gibi birçok farklı veri toplama araçları ile motivasyon, akademik performans ve öğrenme bağımlı değişkenleri üzerinde oyunlaştırmanın etkisi ölçülmüştür. Ulaşılan çalışmalarda en çok tercih edilen oyun elementi puan olup bunu seviye, ödül, rozet, geri bildirim ve yetki takip etmektedir. Bu noktada incelenen çalışmalar, süreçte tercih edilen oyun elementleri nedeniyle oyunlaştırmanın bir ödüllendirme sistemi oluşturduğuna yönelik eleştirileri destekler niteliktedir.

ncelenen çalışmalarda en çok 20-54 katılımcının yer aldığı örneklem olarak kullanılmıştır. Bu noktada çalışmalarda tercih edilen örneklem büyüklüklerinin sonuçlanı genelleyebilmek adına yetersiz kalmaktadır ki bu durum çalışmaların sınırlılıklarında da belirtilmiştir. Araştırma kapsamında incelenen çalışmalarda örneklem düzeyi ilköğretimden yükseköğretime kadar farklı eğitim kademelerinde gerçekleştirilirken aynı zamanda farklı meslek ve yaş gruplarını içeren örneklemler olduğu da belirlenmiştir. Son dönemde eğitimden sağlığa hatta reklam ve pazarlama gibi pek çok farklı alanda oyunlaştırma tercih edilmektedir. ncelenen deneysel çalışmalarda da benzer şekilde hem eğitimin farklı kademelerinde hem de eğitim dışındaki diğer alanlarda gerçekleştirildiği belirlenmiştir.

Yapılan incelemede oyunlaştırmayı ödül sistemi ve aynı zamanda öğrenenler arasındaki rekabeti arttıran ve ilerleyen süreçte öğrencinin motivasyonunu da olumsuz etkilere sebep olabilen bir yaklaşım olarak ele alan çalışmalar bulunmaktadır. (Buckley ve Doyle,

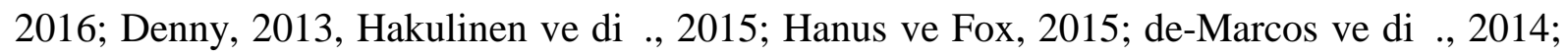
Yıldırım ve Demir, 2014). Tüm bunlar göz önüne alındığında özellikle küçük yaş grubu için oyunlaştırma birçok açıdan istenmeyen durumların oluşmasına neden olabilir. Bu bağlamda 
ilkokulda ve ortaokulda gerçekleştirilen çalışmalar alanyazına katkıda bulunma açısından önemlidir.

Araştırma kapsamında incelenen çalışmalarda, oyun elementleri hem geleneksel sınıf ortamında (Fotaris ve diğ., 2016; Juárez ve Carballo, 2016) hem de farklı teknolojik araçlar yardımıyla öğrenme süreçlerine (Chen ve diğ., 2016) dahil edilmiştir. Dijital araçların oyunlaştırma süreçlerine dahil edilmesi öğretmenin üzerinden önemli bir yükü azaltmaktadır (Samur, 2015). Arkün-Kocadere ve Samur (2016) oyunlaştırma hem fiziksel hem de çevrimiçi sınıflarda kullanılabilen bir yöntem olduğunu belirtmişlerdir ve elde edilen bu bulgu da bu durum ile benzerlik göstermektedir.

Alan yazın incelendiğinde oyun temelli eğitim, oyunlaştırılmış oyun ve oyunlaştırma terimlerinin birbirine çok yakın anlamlar ifade etmekle birlikte araştırma kapsamında incelenen çalışmalarda olduğu gibi oyun temelli öğrenmeye benzer özellikteki uygulamalar da oyunlaştırma kapsamında ele alınmaktadır (Chen ve diğ.,2016; Cózar-Gutierrez ve Sáez-

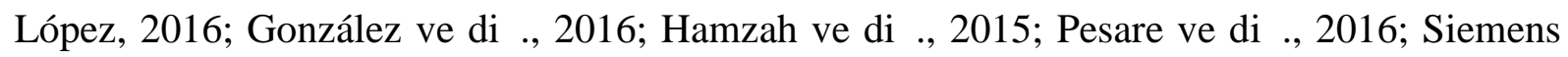
ve di $\breve{g} ., 2015)$.

Araştırmada incelenen çalışmaların araştırma desenleri incelendiğinde en sık tercih edilen (\%33.3) desen ön test son test kontrol gruplu deneysel desendir. Her ne kadar en sik tercih edilen ön test son test kontrol gruplu desen deneysel desen olsa da çalışmaların sonuçlarının objektifliği, tekrar edilebilirliği ve genellenebilirliği gibi pek açından bu oranın çok daha yüksek olması gerekmektedir.

Eğitimde oyunlaştırma yönteminin öğrenen motivasyonuna ve katılımına, öğrenmeye gibi birçok değişken üzerindeki etkisine yönelik var olan tezat oluşturan durum araştırma kapsamında incelenen çalışmaların sonuçlarında da görülmektedir. Araştırma kapsamında oyunlaştırma yönteminin motivasyon üzerindeki etkisine yönelik anlamlı fark 7 (Chen ve diğ., 2016; Cózar-Gutierrez ve Sáez-López, 2016; Fotaris ve diğ., 2016; González ve dĭğ., 2016; Hamzah ve diğ., 2015; Pesare ve diğ., 2016; Siemens ve dĭ̆., 2015) çalışmada elde edilirken 2 (Juárez ve Carballo, 2016; Roper ve Vecera, 2016) çalışmada anlamlı farklılık bulunmamıştır. Juárez ve Carballo (2016) ait olan çalışmada öğrencilerin oyunlaştırmanın bilmedikleri bir şeyi öğrenme sürecinde motivasyonlarına olumlu katkılar verirken bildikleri bir şeyi öğrenmeye devam ederken öğrenme motivasyonunu desteklemediği sonucu elde

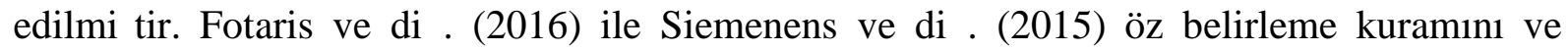
Hamzah ve diğ. (2015) ise Keller'e ait ARCS modelini (Hamzah ve diğ., 2015) temel alarak motivasyon kavramını ele almıştır. 
Cózar-Gutierrez ve Sáez-López (2016), González ve dĭg. (2016) ile Hamzah ve diğ., (2015) olmak üzere incelenen üç çalışmada oyunlaştırmanın öğrenme üzerindeki etkisini olumlu olarak belirlemiştir. Fakat ncelenen çalışmalardan 4 tanesi ise öğrenme üzerinde olumlu etkiler olsa da istatiksel olarak anlamlı fark yaratmadığı yönünde sonuçlar olsa da katılımcılar oyunlaştırma ile öğrenme sürecini daha ilgi çekici bulmuşlardır (Chen ve diğg., 2016; Fotoris ve diğ., 2016; Juárez ve Carballo, 2016; Pesare ve diğ., 2016). Ayrica oyunlaştırma ile öğrencilerin sınıf ortamının doğası gereği var olan disiplininden kaynaklanan baskıdan sıyrılmaları sağlanmış (Fotaris ve diğ., 2016; Pesare ve diğ., 2016) daha fazla deneme yapma firsatı bulmuş (Juárez ve Carballo, 2016; Pesare ve diğ., 2016) ve böylece öğrenciler derste daha aktif katılım göstermişlerdir (Fotaris ve diğ., 2016; Pesare ve diğg., 2016). Ancak Juárez ve Carballo (2016), oyunlaştırmanın teorik içeriklerde öğrenme üzerinde etkili olmadığını belirtmiştir.

Oyunlaştırma ile öğrencilerin birbirleri ile etkileşim kurmaları ve karşılıklı fikirlerini paylaşmaları sağlanırken aynı zamanda problem çözme, eleştirel düşünme ve işbirlikli çalışma becerileri de olumlu etkilenmiştir (Cózar-Gutierrez ve Sáez-López, 2016; Pesare ve diğ., 2016). ncelenen çalışmaların sonucunda öğrencilerin oyunlaştırma ile öğrenme sürecinde gruplar halinde çalıştıklarında performanslarının sürekliliğinin daha uzun süre sağlandığı sonucuna varılmıştır (Pesare ve diğ., 2016). Öğrencilerin öğrenme stilleri üzerinden yapılan analizlerde görsel öğrenen öğrencilerin oyunlaştırma ile öğrenmeleri üzerinde daha olumlu etkiler gerçekleştiğgi belirlenmiştir (Juárez ve Carballo, 2016).

Alan yazında oyunlaştırmanın kullanıldığı deneysel çalışmalarda istatiksel olarak González ve diğ. (2016) nedeni olarak çalışmanın kısa bir sürede gerçekleştirilmesi olduğunu öne sürmektedir. Benzer şekilde Fotaris ve diğ. (2016) ile Juárez ve Carballo (2016) ise verilerin derinlemesine analiz yapılamamasının sebebinin örneklem büyüklügünün yeterli düzeyde olmaması olarak belirtip çalışmaların daha geniş örneklemlerle tekrar edilmesi

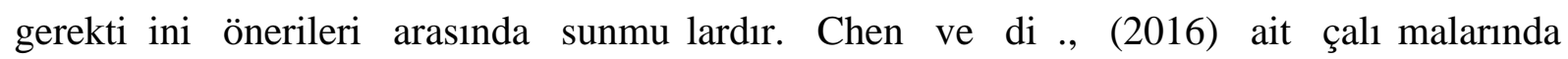
oyunlaştırma yönteminin daha çok uygulamaya yönelik öğrenme alanlarında (müze gezileri, hayvanat bahçeleri ziyareti vb.) uygulanması önerilmiştir. Oyunlaştırmanın öğrenme-öğretme süreçlerinde etkili bir şekilde uygulanabilmesi için öğretmenlerin bu süreci yönetebilmeye yönelik yeterliliklere sahip olması gerektiği dolayısıyla öğretmen yetiştirme programlarında buna yönelik yeniliklere ihtiyaç duyulduğu belirtilmiştir (Cózar-Gutierrez ve diğ. Sáez-López, 2016). 


\section{Öneriler}

Eğitim, bilimde ve teknolojide yaşanan gelişmeler sayesinde sürekli yenilenen içeriğinin olan bir alandır. Ayrıca uygulama aşamasında bu değişime ayak uydurabilmek amacıyla sürekli olarak öğretmenlerin yeni yöntem ve stratejiler geliştirme ihtiyacı doğmaktadır. Bu noktada oyunlaştırma motivasyona yönelik olarak kullanıldığında her derde deva olacak bir yöntem olarak sunulmaktadır (Lee ve Hammer, 2011; Glover, 2013; Kim, 2015). Ancak araştırma kapsamında incelenen çalışmalarda da görüldüğü üzere oyunlaştırmanın uygulamada sınırlılıkları bulunmaktadır. Bu sınırlılıkları aşmak için alınması gereken bazı önlemler ve sürecin planlanmasında dikkat edilmesi gereken bazı noktalar bulunmaktadır.

yi planlanmamış bir öğretim tasarımının yerini herhangi bir oyun elementi alamayacaktır ve öğrenme sürecinde oyunlaştırma yöntemi tercih edilirken öncelikle öğrenme sürecinin temel hedeflerinin, öğrencilerin ihtiyaçlarının, önceki öğrenme durumlarının, öğrencilerin yeteneklerinin vb. özelliklerinin analiz edilmesi gerekir (Eck, 2006; Hanus ve Fox, 2015; Kim 2015; Werbach ve Hunter, 2012). Öğrencilerin ilgisinin sürekliliği için yetenek ve becerilerine uygun zorluk seviyesinde bir oyunlaştırma süreci planlanmalıdır (Nicholson, 2012; Kim, 2015). Süreçte hedeflenen kazanımlar, öğrencinin problem çözme, araştırma yapabilme, eleştirel düşünebilme vb. yaratıcılık gerektiren becerilerine yönelik olmalıdır (Meire, 2000).

Başlangıçta sürecin yeni olmasından dolayı öğrencilerin ilgi ve merak düzeyi yüksek olabilir ancak zamanla ustalaşacaklarından ilgi ve merak giderek azalabilir (Werbach ve Hunter, 2012). Bu nedenle de uzun süreler için planlama yapılırken aşılması gereken engeller, seviye gibi giderek zorlaşan aşamalar vb. eklenerek sürecin bütününde ilgi ve merak öğrenmeye yönelik olarak uygun seviyede tutulabilir (Nakamura ve Csikszentmihalyi, 2002; Nicholson, 2012; Werbach ve Hunter, 2012).

Öğrencileri her bir öğrenme görevi için farklı araçlara (sosyal medya, wiki, blog vb.) yönlendirerek ve her bir aracın farklı puanlar kazandırdığı süreçlerde öğrenciler arasında iş birliği ve paylaşım desteklenmiş olur (Glover, 2013). Bu sayede hem eğlenirken hem de öğrenme ve yararlanılan çevrimiçi araçlar öğretmenlerin işlerini hafifletmeye yardımcı olur (Samur, 2015).

Oyunlaştırma ile hedeflenen davranış değişikliği için bireyler dışarıdan yapılan etkiler ile teşvik edilmektedir. Ancak bu unsurlar (ödül vb.) dış motivasyon üzerinde bir etkide bulunduğundan uzun vadede etkili sonuçlar vermeyeceklerdir bu nedenle de süreçte bireylerin 
içsel motivasyonuna odaklanılması gerekir. Bu aşamada öz-belirleme kuramı çerçevesinde öğrencilere yetki, güç ve seçenekler sunularak özerklik, yetkinlik ve bağlılık hisleri desteklenmelidir (Deci,1971; Deci ve diğ., 2001; Nicholson, 2012; Werbach ve Hunter, 2012). Örneğin; puan kullanılacak ise bu puanlar biriktirilerek başka yetki, boş vakit, gezi vb. ödüller ile değiş tokuş yapılabilmelidir (Porter, 2007). Ancak bu noktada da öğrenciye verilecek olan yetkinin ve boş vaktin net çizgiler ile sınırlandırılmış ve geziye yönelik olarak da öğrenciler ile fikir birliğine varılmış olması gerekmektedir (Porter, 2007).

Araştırma kapsamında incelenen çalışmalarda görüldüğü gibi ödül oyunlaştırmada en çok tercih edilen oyun elementlerinden biridir. Çünkü ödüller her ne kadar bireylerin dış motivasyonunu etkileyerek uzun vadede istenen sonuçların alınması noktasında engeller oluşturuyor olsa da her birey için bir teşvik unsurudur (Roper ve Vecera, 2016). Burada önemli nokta ödüllerin nasıl ve hangi öğrenme hedefi için kullanıldığıdır (Pink, 2009). Ödüller, öğrenme hedefi bireyin yaratıcılık kullanmasını gerektirmiyorsa ve öğrenciler üzerinde kontrol ve baskı sistemi olarak kullanılmazsa bireylerin içsel motivasyonunun olumsuz yönde etkilenmesine engel olunabilir. Bireylerin teşvik edilmesi için ödül kullanımının ardından bireyin ilgi ve merakı devam etmiyorsa ödül verilmeye devam edilmemelidir (Pink, 2009). Ayrıca kullanılacak olan ödüle öğrenenlerle birlikte karar vermek, ödül kullanılacak ise öğrenenlerin hangi davranışın ya da performansın net çizgiler iler ödüllendirileceğine yönelik olarak bilgilendirilmesi ve sürece dahil olan tüm bireyler için adil bir biçimde kullanılması daha etkili sonuçlar alınmasına yardımcı olabilir (Porter, 2007).

Eğitimin vazgeçilmez bir parçası olan ölçme değerlendirme oyunlaştırma yönteminin kullanıldığı süreç için de önem arz etmektedir ve bu nedenle öğrenenlerin hedefe ulaşma konusunda başarısını ölçmeye yönelik uygun yöntem ve araç belirlenmelidir (Kim, 2015; Lee ve Hammer, 2011). Oyun elementlerinden liderlik tablosu, puan ve rozet, öğrencilerin resmi not değerlendirilmesi için kullanılmamalıdır (Fotoris ve diğ.,2016). Arkün-Kocadere ve Çağlar (2015) tarafından özellikle liderlik tablosunun öğrenenler arasında rekabetin oluşmasına neden olması ve alt sıralardaki öğrenenlerin motivasyonunu olumsuz etkilemesi nedeniyle kullanılmaması önerilmektedir.

Her birey kendi gelişimini izleyerek motive olmaktadır (Ryan ve Deci, 2000a; Werbach ve Hunter, 2012). Bundan dolayı süreçte kullanılan oyun elementleri (liderlik tablosu, rozet, puan vb.) bireylere geri bildirim verme amaciyla kullanılmalıdır (ArkünKocadere ve Çağlar, 2015; Glover, 2013; Nicholson , 2012). Geri bildirimler düzenli ve sistemli verilmeli ve bireyin öğrenme durumunu özetlemek amacı ile kullanılmalıdır. 
Öğrencilere sunulan geri bildirim ile süreci kapsayan bir değerlendirme yapılırken aynı zamanda bu geri bildirimi işleyebileceği öğrenme ödevi ile öğrencilere ikinci şans verilerek öğrenme daha kalıcı hale getirilebilir (Butler, Marsh, Slavinsky ve Baraniuk, 2014). Bu nedenle öğrencilere oyunlaştırmanın kullanıldığı bir öğrenme sürecinde de geri bildirimleri takip eden öğrenme görevleri verilmelidir.

Oyunlaştırma yöntemine yönelik yapılan planlama ile oyun tasarımı birbirinden çok farklı alanlar değildir. Etkili oyun tasarımı için oyuncu tipleri analiz edilmektedir ve oyunlaştırmada da bu oyuncu tiplerinden yararlanılabilir (Kim, 2015; Nicholson, 2012; Werbach ve Hunter, 2011). Her oyuncu tipinin amacına uygun ve ilgisine yönelik unsurlar sürece dahil edilerek tüm sınıfın başarısını hedeflenmelidir. Oyun ile oyunlaştırmanın benzerlikler içerdiği ve oyuncu oyuna gönüllü olarak dahil olduğu göz önüne alındığında oyunlaştırma yönteminin kullanıldığı bir öğrenme sürecine öğrenciler bir gereklilik nedeniyle dahil edilmemelidir (Hanus ve Fox, 2015; Nickholson, 2012). Yani öğrencilere katılma konusunda bir seçim şansı sunulmalıdır 


\section{Kaynakça}

Arkün-Kocadere, S. ve Çağlar, S. (2015). The design and implementation of gamified assesment. Journal of e-Learning and Knowledge Society, 11(3), 85-99.

Arkün-Kocadere, S., ve Samur, Y. (2016). Oyundan oyunlaştırmaya. içinde A. şman, F. Odabaşı, ve B. Akkoyunlu Eğitim Teknolojileri Okumaları (s. 397-414). TojetSakarya Üniversitesi.

Bruckman, A. (1999, Mart). Can educational be fun? Game Developer's Conference'da sunulan bildiri San Jose California.

Buckley, P., ve Doyle, E. (2016). Gamification and student motivation. Interactive Learning Environments, 24(6), 1162-1175.

Butler, A. C., Marsh, E. J., Slavinsky, J. P., ve Baraniuk, R. G. (2014). Integrating cognitive science and technology improves learning in a stem classroom. Educational Psychology Review, 26(2), 331-340.

Büyüköztürk, Ş., Kılıç Çakmak, E., Akgün, Ö. E., Karadeniz, Ş., ve Demirel, F. (2016). Bilimsel araştırma yöntemleri. Ankara: Pegem Akademi.

Chen, C.-H., Liu, G.-Z., ve Hwang, G.-J. (2016). Interaction between gaming and multistage guiding strategies on students' field trip mobile learning performance and motivation. British Journal of Educational Technology, 47(6), 1032-1050.

Cheong, C., Cheong, F. ve Filippou, J. (2013, Haziran). Quick quiz: A gamified approach for enhancing learning. PACIS 2013 kongresinde sunulan bildiri. Pacific Asia Conference on Information System, Güney Kore.

Cózar-Gutiérrez, R., ve Sáez-López, J. M. (2016). Game-based learning and gamification in initial teacher training in the social sciences: An experiment with Minecraftedu. International Journal of Educational Technology in Higher Education, 13(2), 1-11.

Csikszentmihalyi, M. (2014). Flow and the foundations of positive psychology. Hollanda: Springer

Deci, E. L. (1971). Effect of externally mediated rewards on instrinsic motivation . Journal of Personality and Social Psychology, 18(1), 105-115.

Deci, E. L., ve Ryan, R. M. (2008). Self-determination theory: A macrotheory of 
human motivation, development, and health. Canadia psychology/Psychologie canadienne, 49(3), 182-185.

Deci, E. L., Koestner, R., ve Ryan, R. M. (2001). Extrinsic rewards and intrinsic motivation in education: reconsidered once again. Review of Educational Research, 71(1), 1-27.

de-Marcos, L., Domínguez, A., Saenz-de-Navarrete, J., ve Pagés, C. (2014). An empirical study comparing gamification and social networking on e-learning. Computers \& Education, 75, 82-91.

Denny, P. (2013, Nisan). The effect of virtual achievements on student engagement. Human Factors in Computing Systems kongresinde sunulan bildiri, SIGCH, Paris, Fransa.

Deterding, S., Dixon, D., Khaled, R., ve Nacke, L. (2011, Eylül). From game design elements to gamefulness: defining gamification. 15th International Academic MindTrek Conference: Envisioning Future Media Environments konferansinda sunulan bildiri, ACM, Amerika Birleşik Devletleri.

Deterding, S., O’Hara , K., Sicart, M., Dixon, D., ve Nacke, L. (2011). Gamification: using game design elements in non-gaming contexts. CHI, 2011 sunulan bildiri, ACM, Vancouver, Kanada.

Deterding, S., Sicart, M., Nacke, L., O’Hara, K., ve Dixon, D. (2011,). Gamification: Toward a definition. CHI 2011 sunulan Bildiri Gamification Workshop, Vancouver, Kanada.

Domínguez, A., Saenz-de-Navarrete, J., de-Marcos, L., Fernández-Sanz, L., Pagés, C., ve Martínez-Herráiz, J.-J. (2013). Gamifying learning experiences: Practical implications and outcomes. Computers \& Education, 63, 380-392.

Dong, T., Dontcheva, M., Joseph, D., Karahalios, K., Newman, M. W., Ackerman, M., ve Ackerman, M. S. (2012, Mayıs). Discovery-based games for learning software, Human Factors in Computing Systems kongresinde sunulan bildiri, SIGCH, Paris, Fransa.

Eck, R. V. (2006). Digital game-based learning: It's not just the digital natives who are restless. Educause Review , 41(2), 16-30.

Fitz-Walter, Z., Tjondronegoro, D. W., ve Wyeth, P. (2011). Orientation passport: using gamification to engage university students. $23^{\text {rd }}$ Australian Computer-Human Interaction Conference sunulan bildiri. Canberra: ACM. 
Fotaris, P., Mastoras, T., Leinfellner, R., ve Rosunally, Y. (2016). Climbing up the leaderboard: An empirical study of applying gamification techniques to a computer programming class. The Electronic Journal of e-Learning, 14(2), 94-110.

Gagné, M., ve Deci, E. L. (2005). Summary self-determination theory and work motivation. Journal of Organizational Behavior,26 (4), 331-362.

Glover, I. (2013). Play as you learn: gamification as a technique for motivating learners. World Conference on Educational Multimedia, Hypermedia and Telecommunications sunulan bildiri. AACE, Waynesville, NC, Amerika Birleşik Devletleri.

González, C. S., Gómez , N., Navarro , V., Cairós, M., Quirce, C., Toledo, P., ve MarreroGordillo, N. (2016). Learning healthy lifestyles through active videogames, motor games and the gamification of educational activities. Computers in Human Behavior, $55,529-551$.

Hakulinen, L., Auvinen, T., ve Korhonen, A. (2015). The effect of achievement badges on students' behavior: an empirical study in a university- level computer science course. International Journal of Emerging Technologies in Learning (iJET), 10(1), 18-29.

Hamzah, W. M., Ali, N. H., Saman, M. M., Yusoff, M. H., ve Yacob, A. (2015). Influence of gamification on students' motivation in using e-learning applications based on the motivational design model. International Journal of Emerging Technology Learning, 10(2), 30-34.

Hanus, M. D., ve Fox, J. (2015). Assessing the effects of gamification in the classroom: a longitudinal study on intrinsic motivation, social comparison, satisfaction, effort, and academic performance. Computers \& Education, 80, 152-162.

Järvinen, A. (2008). Games without frontiers: Theories and methods for game studies and design. (Yayımlanmıs Doktora Tezi) Tampere University, Finlandiya.

Juárez, G. H., ve Carballo, M. M. (2016). Learning gains, motivation and learning styles in a gamified class. International Journal of Engineering Education, 32(1), 438-447.

Juul, J. (2003, Kasim). The game, the player, the world: Looking for a heart of gamenes. Level Up: Digital Games Research Conference sunulan bildiri, Utrecht University, Hollanda.

Kim, B. (2015). Understanding gamification . Library Technology Reports, 51(2), 5-35. 
Kim, B., Park, H., ve Baek, Y. (2009). Not just fun, but serious strategies: Using metacognitive strategies in game-based learning. Computers \& Education, 52(4), 800-810.

Lee, J. J., ve Hammer, J. (2011). Gamification in education: what, how, why bother? Academic Exchange Quarterly, 15(2), 1-5.

Meire, D. (2000). The accelerated learning handbook. McGrow Hill.

Nakamura, J., ve Csikszentmihalyi, M. (2002). The concept of flow. çinde C. R. Snyder, ve S. J. Lopez, Handbook of Possitive Psychology (ss. 89-105). New York: Oxford University Press.

Nicholson, S. (2012). A user-centered theoretical framework for meaningful gamification. Games+Learning+Society 8.0, Madison.

Pesare, E., Roselli, T., Corriero, N., ve Rossano, V. (2016). Game-based learning and gamification to promote engagement and motivation in medical learning contexts. Smart Learning Environments, 3(5), 1-11.

Piano Staircase. (2009). The fun theory,http://www.thefuntheory.com/piano-staircase adresinden elde edildi.

Pink, D. H. (2009). Drive . (Göktem, L. Çev.) Kapital Medya Hizmetleri.

Porter, S. M. (2007). The impact of a school-wide token economy on behavior, attendance, and academics at morgan high school. (Yayımlamıs yüksek lisans tezi) Marietta College, Ohio, Amerika Birleşik Devletleri.

Prensky, M. (2007). Dijital game-based learning. St. Paul: Paragon House Edition.

Roper, Z. J., ve Vecera, S. P. (2016). Funny money: The attentional role of monetary feedback detached from expected value. Atten Percept Psychophys(78), 2199-2212.

Ryan, R. M., ve Deci, E. L. (2000a). Intrinsic and extrinsic motivations: classic definitions and new directions. Contemporary Educational Psychology, 25, 54-67.

Ryan, R. M., ve Deci, E. L. (2000b). Self-determination theory and facilitation of instrinsic motivation, social development, and well-being. American Psychologist, 55(1), 68-78.

Samur, Y. (2015). Gamifying a hybrid graduate course. Global Learn Conference sunulan bildiri, Fern Universitat in Hagen, Berlin, Germany.

Samur, Y. (2016). Dijital oyun tasarımı . stanbul: Pusula. 
Siemens, J. C., Smith, S., Fisher, D., Thyroff, A., ve Killian, G. (2015). Level up! the role of progress feedback type for encouraging intrinsic motivation and positive brand attitudes in public versus private gaming contexts. Journal of interactive marketing, $32,1-12$.

Türker, P. (2016). Beyin temelli öğrenme ve oyun temelli öğrenme. içinde E. A. Yılmaz, Oyunlaştırma (ss. 232-235). stanbul: Abaküs.

Werbach, K. (2014). (Re)defining gamification. Persuasive Technology Konferansinda sunulan bildiri. Springer, sviçre.

Werbach, K., ve Hunter, D. (2012). For the win . Phiedlphia: Wharton Digital Press .

Yıldırım, ., ve Demir, S. (2014). Oyunlaştırma ve eğitim. International Journal of Human Science, 11(1), 655-670.

\section{Extended Summary}

Gamification is the use of game design elements in non-game context (Arkgün-Kocadere \& Samur, 2016; Deterding, Sicart, Nacke, O’Hara, \& Dixon, 2011; Werbach, 2014; Werbach \& Hunter, 2012). Recently, gamification has been preferred in learning and teaching process because of its effects and direct relation with motivation.

Motivation, the reason of doing something, is the interaction between individual and in time action and situation (Ryan \& Deci, 2000a; Werbach \& Hunter, 2012). Intrinsic motivation means that an individual performs an action because of making himself or herself satisfied. If somebody performs an action because of avoiding punishment or gaining a reward, the reason of this behaviour is called extrinsic motivation. Self-determination theory is an established theory for explaining the intrinsic motivation, external motivation and amotivation (Ryan \& Deci, 2000b). It suggests that autonomy, competence and relatedness must be supported when processes that support individuals' internal motivation are planned. Self-determination theory is explained that amotivation is the state of lack of an intention to act. One of the points that should be taken into account in the gamification within the framework of this theory; the game elements must not use the form of control and pressure mechanisms on the individual.

Education has similarities with gamification. Every academic year is planned in line with the determined instructional objective, students gain points when they achieve, the scores become grades, and at the end of the year, they are entitled to the next level, the upper class 
(Buckley \& Doyle, 2016; Lee \& Hammer, 2011). The results of examined research conducted with this regard have put forward different opinions. From these views, gamification not only makes meaningful differences on students' learning but it may also affect their motivation negatively. In addition, there is a competition among learners in the processes where gamification is used, and this creates a contradiction with many learning theories.

Therefore, in this research study, a content analysis was carried out to analyse and evaluate the effect of gamification on students' motivation. Suggestions were made in the light of the studies examined within the scope of the research. Within the limited scope of the study, nine articles were reached by using the keywords "gamification", "motivation" and "experimental" in an academic search engine because only experimental studies related with the effect of gamification on motivation were searched and the results are presented.

The results of research studies conducted with gamification in education presents various opinions. Game elements were implemented to the classroom settings with and without the help of technological tools. Some research studies were defined themselves as game based learning studies, however they were actually gamification applications because there was no game used within the studies (Chen et al., 2016; Cózar-Gutierrez \& Sáez-López, 2016; González et al., 2016, Hamzah et al., 2015; Pesare et al., 2016;Siemens et al., 2015).

When the most commonly used game elements were analysed, it was seen that points, levels, rewards, and badges were the most preferred game elements in the studies similar to the views in the literature (Buckley \& Doyle, 2016; de-Marcos, Domínguez, Saenz-deNavarrete \& Pagés, 2014; Denny, 2013; Hakulinen, Auvinen, Korhonen, 2015; Hanus \& Fox, 2015;). Motivation, learning, and academic performance were the most studied dependent variables, while the most studied independent variables were the process with gamification, and game applications, and e-learning environments. The effects on the dependent variables mentioned in gamification were explained by the participants from the primary school to undergraduate level so different results were presented. According to the findings, there were significant differences on motivation in seven studies (Chen et al., 2016; Cózar-Gutierrez \& Sáez-López, 2016; Fotoris, Mastoras, Leinfeliner \& Rosunally, 2016; González et al., 2016; Hamzah et al., 2015; Pesare et al., 2016; Siemens vd., 2015) while no significant difference was found in two studies (Juárez \& Carballo, 2016; Roper \& Vecera, 2016)

Results showed that three out of seven studies had positive effect of gamification on learning. However, the rest of four studies had positive results (e.g. the students found the learning process interesting) with gamification but did not show significant difference on 
learning. In addition, the students had more learning opportunities through gamification (Juárez \& Carballo, 2016; Pesare et al., 2016), students were able to avoid the pressure of existing classroom discipline (Fotoris et al., 2016; Pesare et al., 2016), hence, they showed active participation in class (Fotoris et al., 2016; Pesare et al., 2016). Furthermore, the students were able to interact and share ideas with each other, at the same time problem solving, critical thinking and cooperative work skills were also positively influenced by using gamification in learning process. In one study, gamification made positive contributions to students' motivation in the process of learning a new content whereas gamification did not support students' motivation with existing knowledge (Juárez \& Carballo, 2016). Besides it was suggested that gamification should be used with application activities because it was not found effective on learning in the theoretical context (Chen et al., 2016).

As a result of the examined studies and the literature review, when gamification is used for motivation, it is presented as a panacea. However, in order to obtain positive results on students' learning and motivation with gamification, a well-planned instructional design is needed first. Although gamification works in short-term activities, when effective instructional design is not created, no game elements will be able to help learning or motivation for long-term. Therefore, it may cause that the desired goals may not be reached at the end of the process. In order for the gamification to be effectively implemented in the learning and teaching process, teacher needs to have competency to manage this process, and thus there is a need for innovations in teacher training programs (Cózar-Gutierrez \& SáezLópez, 2016). Finally, appropriate assessment tools and methods should be identified to measure the success of the gamified process (Kim, 2015; Lee \& Hammer, 2011). Getting help from online tools in this process is helpful because it creates a burden on teachers' workload (Samur,2015). 
Tablo 3.Araştırma Kapsamında ncelenen Çalışmalarda Kullanılan Veri Toplama Araçları

\begin{tabular}{|c|c|c|c|c|c|c|c|c|}
\hline & \multicolumn{2}{|c|}{$\begin{array}{ll}\text { Motivasyon } & \text { Akademik Performans ve } \\
\text { Öğrenme }\end{array}$} & \multicolumn{2}{|c|}{$\begin{array}{l}\text { Öğrenci } \\
\text { Görüş̧meleri }\end{array}$} & $\begin{array}{l}\text { Öğrenci } \\
\text { Davranışları }\end{array}$ & Öğrenme Stili Tutum & Akış & $\begin{array}{l}\text { Biyometrik } \\
\text { Özellikler }\end{array}$ \\
\hline $\begin{array}{l}\text { Hamzah, Ali, } \\
\text { Saman,Yusoff ve } \\
\text { Yacob, } 2015\end{array}$ & $\begin{array}{l}\text { Instructional } \\
\text { Materials } \\
\text { Motivation Survey } \\
\text { (IMMIS) }\end{array}$ & & & & & & & \\
\hline $\begin{array}{l}\text { Siemens, Smith, } \\
\text { Fisher,Thyroff ve } \\
\text { Killion, } 2015\end{array}$ & $\begin{array}{l}\text { Ryan'1n } \\
\text { motivasyon } \\
\text { envanteri, 1982; } \\
\text { McAuley, Duncan } \\
\text { \& Tammen, } 1989\end{array}$ & & & & & $\begin{array}{l}\text { Akış } \\
\text { Testi } \\
\text { (Jackson } \\
\text { ve } \\
\text { Marsh, } \\
\text { 1995) }\end{array}$ & & \\
\hline $\begin{array}{l}\text { Chen, Liu ve } \\
\text { Hwang, } 2016\end{array}$ & $\begin{array}{l}\text { Hwan, Yang \& } \\
\text { Wang, 2013, } \\
\text { tarafindan } \\
\text { geliştrilen anket } \\
\text { uyarlanmıştır. }\end{array}$ & $\begin{array}{l}\text { Tam puanın } 100 \\
\text { olduğu } 20 \text { çoktan } \\
\text { seçmeli soru }\end{array}$ & & & & & & \\
\hline $\begin{array}{l}\text { Cózar-Gutierrez } \\
\text { ve Sáez-López, } \\
2016\end{array}$ & $\begin{array}{l}\text { Loras \& } \\
\text { Steenkamp, 2005, } \\
\text { uyarlanan test }\end{array}$ & $\begin{array}{l}\text { Sáez-López \& } \\
\text { Domínguez, } 2013 \\
\text { uyarlanan test \& } \\
\text { Hiltz, Coppola, } \\
\text { Rotter, Turoff, 2000, } \\
\text { uyarlanan test }\end{array}$ & & & & & & \\
\hline $\begin{array}{l}\text { Fotoris,Mastoras, } \\
\text { Leinfeliner ve } \\
\text { Rosunally, } 2016\end{array}$ & $\begin{array}{l}15 \text { soruluk } \\
\text { araştırma grubu } \\
\text { tarafından } \\
\text { geliştirilen anket }\end{array}$ & $\begin{array}{l}\text { Quiz, final, programla } \\
\text { projesi }\end{array}$ & $\begin{array}{l}\text { Süreç } \\
\text { hakkındaki } \\
\text { görüş̧ ve } \\
\text { önerileri } \\
\text { sorulmuştur. }\end{array}$ & $\begin{array}{l}\text { Derse } \\
\text { vaktinde } \\
\text { gelme, } \\
\text { derse } \\
\text { devam, } \\
\text { ders } \\
\text { materyalini } \\
\text { edinme }\end{array}$ & & & & \\
\hline
\end{tabular}


Ege Eğitim Dergisi 2017 (18) 2: 857-886

Oyunlaştırma Yönteminin Öğrencilerin Motivasyonları Üzerine Etkisi

\begin{tabular}{|c|c|c|c|c|c|c|c|c|c|}
\hline $\begin{array}{l}\text { González, } \\
\text { Gómez, Navarro, } \\
\text { Cairós, Quirce, } \\
\text { Toledo ve } \\
\text { Marrero- } \\
\text { Gordillo, } 2016\end{array}$ & $\begin{array}{l}\text { González- } \\
\text { González, Cairós- } \\
\text { González \& } \\
\text { Navarro- } \\
\text { Adelantado, } 2013 \\
\text { Emodiana }\end{array}$ & $\begin{array}{l}\text { Serra-Majem, Ribas, } \\
\text { Ngo, Ortega, García, } \\
\text { Pérez-Rodrigo \& } \\
\text { Aranceta, 2004, } \\
\text { KIDMED,"González- } \\
\text { González, Cairós- } \\
\text { González \& Navarro- } \\
\text { Adelantado, } 2013 \\
\text { Emodiana" }\end{array}$ & & $\begin{array}{l}\text { Video } \\
\text { kayitları, } \\
\text { kullanıcı } \\
\text { deneyim } \\
\text { anketi }\end{array}$ & & $\begin{array}{l}\text { Alfageme } \\
\& \\
\text { Sanchez, } \\
2003 \\
\text { uyarlanan } \\
\text { test }\end{array}$ & & $\begin{array}{l}\text { Kilo, boy, kemik yoğunluğu, } \\
\text { vücut kitle indeksi, nabız, kalp } \\
\text { ritmi }\end{array}$ & $\begin{array}{l}\text { González Marqués, } \\
\text { Fernández Guinea, Pérez } \\
\text { Hdez, Santamaría, } 2004 \\
\text { (BASC) }\end{array}$ \\
\hline $\begin{array}{l}\text { Juárez ve } \\
\text { Carballo, } 2016\end{array}$ & $\begin{array}{l}\text { çsel motivasyon, } \\
\text { dişsal motivasyon } \\
\text { ve } \\
\text { motivasyonsuzluğu } \\
\text { belirlemeye } \\
\text { yönelik } 25 \\
\text { maddeden oluşan } \\
\text { 4lü likert tipi anket }\end{array}$ & $\begin{array}{l}\text { Araştırma grubu } \\
\text { tarafından hazırlanan } \\
\text { doğru yanlış } \\
\text { sorularından oluşan } \\
\text { bir test \& Vize, final, } \\
\text { final projesi, ödevler }\end{array}$ & $\begin{array}{l}\text { Nasıl } \\
\text { öğrenme } \\
\text { süreçleri } \\
\text { istersiniz: }\end{array}$ & & VARK & & & & \\
\hline $\begin{array}{l}\text { Pesare, Roselli, } \\
\text { Corriero ve } \\
\text { Rossano, } 2016\end{array}$ & Anket & Bilgi testi & & & & & & & \\
\hline Frekans (f) & 9 & 5 & 2 & 2 & 1 & 1 & 1 & 1 & 1 \\
\hline Yüzde (\%) & 34.6 & 19.2 & 7.7 & 7.7 & 3.85 & 3.85 & 3.85 & 3.85 & 3.85 \\
\hline
\end{tabular}


Ege Eğitim Dergisi 2017 (18) 2: 857-886

Oyunlaştırma Yönteminin Öğrencilerin Motivasyonları Üzerine Etkisi

Tablo 4. Araştırma Kapsamında ncelenen Çalışmalarda Kullanılan Oyun Elementleri

\begin{tabular}{|c|c|c|c|c|c|c|c|c|c|c|c|}
\hline Yazar & Puan & Seviye & Ödül & Rozet & Geri & Liderlik & Yetki/Sorumluluk & Meydan & Özelleştirme & lerleme & Zaman Toplam \\
\hline & & & & & Bildirim & Tablosu & & Okuma & & Çubuğu & \\
\hline Hamzah, Ali, Saman, Yusoff ve Yacob, 2015 & & $\mathrm{x}$ & $\mathrm{x}$ & $\mathrm{x}$ & & $\mathrm{x}$ & $\mathrm{x}$ & $\mathrm{x}$ & & & 6 \\
\hline Siemens, Smith, Fisher, Thyroff ve Killion, 2015 & & & & & & & $\mathrm{x}$ & & & $\mathrm{x}$ & 2 \\
\hline Chen, Liu ve Hwang, 2016 & $\mathrm{x}$ & $\mathrm{x}$ & & & $\mathrm{x}$ & & & & & & 3 \\
\hline Cózar ve Sáez-López, 2016 & & & & & $\mathrm{x}$ & & $\mathrm{x}$ & & $\mathrm{x}$ & & 3 \\
\hline Fotoris,Mastoras, Leinfeliner ve Rosunally, 2016 & $\mathrm{x}$ & & & $\mathrm{x}$ & $\mathrm{x}$ & $\mathrm{x}$ & & & & & 4 \\
\hline González, Gómez, Navarro, Cairós, Quirce, Toledo & & & & & & & & & & & 5 \\
\hline ve Marrero-Gordillo, 2016 & $\mathrm{x}$ & & & $\mathrm{x}$ & & $\mathrm{x}$ & & $\mathrm{x}$ & & & $\mathrm{x}$ \\
\hline Juárez ve Carballo, 2016 & $\mathrm{x}$ & $\mathrm{x}$ & & $\mathrm{x}$ & & & & & & & 3 \\
\hline Pesare, Roselli, Corriero ve Rossano, 2016 & $\mathrm{x}$ & $\mathrm{x}$ & $\mathrm{x}$ & & & & & & $\mathrm{x}$ & & 4 \\
\hline Roper ve Vecera, 2016 & & & $\mathrm{x}$ & & & & & & & & 1 \\
\hline Frekans (f) & 5 & 4 & 4 & 4 & 3 & 3 & 3 & 2 & 1 & 1 & 1 \\
\hline Yüzde (\%) & 16.1 & 12.9 & 12.9 & 12.9 & 9.6 & 9.6 & 9.6 & 6.4 & 3.23 & 3.23 & 3.23 \\
\hline
\end{tabular}

*Cózar \& Sáez-López tarafından gerçekleştirilen çalışmada oyun elementlerine çalışmanın tamamı incelenerek karar verilmiştir. 
Ege Eğitim Dergisi 2017 (18) 2: 857-886

Oyunlaştırma Yönteminin Öğrencilerin Motivasyonları Üzerine Etkisi

Tablo 10. Araştırma kapsamında incelenen çalışmalar

\begin{tabular}{|c|c|c|c|c|}
\hline Yazar & Ülke & Araştırma Deseni & Oyun Elementi & Sonuç \\
\hline Hamzah, Ali, Saman, Yusoff ve Yacob, 2015 & Malezya & $\begin{array}{l}\text { Son test kontrol gruplu yarı } \\
\text { deneysel desen }\end{array}$ & $\begin{array}{l}\text { Düzey, puan, ödül, liderlik } \\
\text { tablosu, meydan okuma, yetki }\end{array}$ & Olumlu \\
\hline Siemens, Smith, Fisher,Thyroff ve Killion, 2015 & Amerika & $\begin{array}{l}\text { Ön-test son-test tek gruplu } \\
\text { deneysel desen }\end{array}$ & Yetki ve ilerleme çubuğu & Olumlu \\
\hline Chen, Liu ve Hwang, 2016 & Tayvan & $\begin{array}{l}\text { Ön-test son-test kontrol } \\
\text { gruplu deneysel desen }\end{array}$ & Puan, geri bildirim, düzey & Olumlu \\
\hline Cózar ve Sáez-López, 2016 & spanya & $\begin{array}{l}\text { Son test kontrol gruplu yarı } \\
\text { deneysel desen }\end{array}$ & Ödül ve düzey & Olumlu \\
\hline Fotoris,Mastoras, Leinfeliner ve Rosunally, 2016 & ngiltere & $\begin{array}{l}\text { Son test kontrol gruplu yarı } \\
\text { deneysel desen }\end{array}$ & $\begin{array}{l}\text { Rozet, puan, geri bildirim, } \\
\text { liderlik tablosu }\end{array}$ & Olumlu \\
\hline $\begin{array}{l}\text { González, Gómez, Navarro, Cairós, Quirce, Toledo ve } \\
\text { Marrero-Gordillo, } 2016\end{array}$ & spanya & $\begin{array}{l}\text { Ön-test son-test kontrol } \\
\text { gruplu deneysel desen }\end{array}$ & $\begin{array}{l}\text { Rozet, puan, meydan okuma, } \\
\text { liderlik tablosu, olumlu geri } \\
\text { bildirim }\end{array}$ & Olumlu \\
\hline Juárez ve Carballo, 2016 & Meksika & $\begin{array}{l}\text { Ön-test son-test kontrol } \\
\text { gruplu desen }\end{array}$ & Puan, düzey, rozet & $\begin{array}{l}\text { Olumlu ancak anlamlı fark } \\
\text { bulunmamıştır. }\end{array}$ \\
\hline Pesare, Roselli, Corriero ve Rossano, 2016 & talya & $\begin{array}{l}\text { Tek gruplu ön-test son-test } \\
\text { kontrol gruplu deneysel } \\
\text { desen }\end{array}$ & $\begin{array}{l}\text { Puan, düzey, ödül, liderlik } \\
\text { tablosu, özelleştirme }\end{array}$ & Olumlu \\
\hline Roper ve Vecera, 2016 & Amerika & $\begin{array}{l}\text { Son test kontrol gruplu } \\
\text { desen }\end{array}$ & Ödül & $\begin{array}{l}\text { Olumlu ancak anlamlı fark } \\
\text { bulunmamıştır. }\end{array}$ \\
\hline
\end{tabular}

